Acta vet. scand. $1973,14,57-68$.

From the Department of Medicine, Veterinary College of Norway, Oslo.

\title{
DIFFERENTIATION OF EIMERIA SPECIES INFECTING SHEEP DURING THE GRAZING SEASON ON PERMANENT AND NEW PASTURES UNDER NORWEGIAN CONDITIONS
}

\author{
By \\ Oddvar Helle and Mosaad Hilali*
}

HELLE, ODDVAR and MOSAAD HILALI: Differentiation of Eimeria species infecting sheep during the grazing season on permanent and new pastures under Norwegian conditions. Acta vet. scand. 1973, 14, 57-68. - The total and differential oocyst counts of the different Eimeria species in the faeces of Norwegian ewes and lambs were investigated at weekly intervals during the grazing period on permanent and new pastures. The total oocyst counts of lambs on permanent pastures were significantly higher than those on new pastures 3-6 weeks after the beginning of the grazing period. This demonstrates that the oocysts had survived the winter in the pasture.

Species differentiation indicated that E. ahsata, E. arlongi, E. crandallis, E. ninakohlyakimovae, E. faurei and E. parva are able to survive the winter in the pasture. E. crandallis occurred in the greatest numbers, and this species might be an important contributor to the clinical symptoms which are frequently observed in Norwegian lambs about $2-3$ weeks after the beginning of the grazing period. There were on the other hand, indications that E. pallida has little ability to survive the winter in the pasture. The results were generally similar for most of the species during 2 successive years.

The total number of oocysts in the faeces of ewes was low on new as well as on permanent pastures, and the species differentiation showed negligible differences. Consequently, it was concluded that the ewes could not be the source of the high oocyst numbers in lambs on the permanent pastures.

coccidiosis; Eimeria; pasture; sheep.

- Participation in this work was supported by a grant from the Norwegian Agency for International Development (NORAD). Present address: Department of Parasitology, Faculty of Veterinary Medicine, Cairo University, Giza, UAR. 
It has previously been demonstrated that oocysts which had survived the winter in pastures were the main source of coccidial infections in lambs on spring pastures in Norway (Helle 1964, 1967, 1970 and 1971b). This was clearly observed when the oocyst counts for a group of lambs grazing on permanent pasture were compared with another group on new pasture. The lambs of the former group showed a significantly higher. oocyst count from 16 days after the beginning of the grazing period.

A survey of the literature showed that little information is available on the occurrence of different Eimeria spp. in sheep. Studies on the incidence of Eimeria spp. in individual faecal samples have been carried out by Christensen (1938), Shah (1963), Joyner et al. (1966), Lizcano Herrera \& Romero Rodriguez (1969), Masi \& Usher (1970), Michael \& Probert (1970), Rohde \& Jungmann (1970), Soltys (1970) and Tsaglis (1970). However, data on the seasonal variations of different Eimeria spp. were almost non-existent. Preliminary observations showed that there is an indication of some seasonal variation among the Eimeria spp. infecting sheep (Pout et al. 1966, Helle 1971b).

The present investigations were conducted with the aim of studying the occurrence of the different Eimeria spp. in ewes and lambs on permanent and new pastures during the grazing period. The major aim was to identify the species which contribute to the significant increase in the oocyst count in the faeces of lambs from 16 days after the start of the grazing period. This study was carried out in 1970 and 1971. In 1970 a group of housed lambs were included in the experiments for comparative purposes.

\section{MATERIALS AND METHODS}

The farm. The investigations were carried out near Oslo on the farm, Wøyen, which has been described by Helle (1971b).

The pastures. As the fields in Eastern Norway are covered with snow from December to April, the grazing period is usually from May to the end of October. In 1970 the experiment covered the period from 20 May until 30 September, while in 1971 the grazing periods was from 19 May until 15 September.

In 1970 , as well as in 1971 , the same two permanent pastures (Nos. 1 and 2) were used. They had previously been grazed by sheep for about 10 years. They have also been described by Helle 
(1971b). Two pastures, not previously used for grazing by sheep, and called new pastures, were used only in 1970. One of them had been grazed by cattle for some years, while the other had not been grazed for several years. The pastures were normally stocked with sheep.

Meteorological conditions. The mean monthly temperature and the number of days with snow cover were taken from the records of the Blindern meteorological station. The data concerning precipitation were obtained from Stovi precipitation station (Table 1) (Helle 1971b). The lowest temperatures which were recorded at Blindern during the winters preceding each grazing period were -21.4 in February 1970 and -17.2 in March 1971.

Table 1. Mean monthly temperatures and number of days within each month with snow cover at Blindern meteorological station, and the total monthly precipitation at Stovi precipitation station.

\begin{tabular}{|c|c|c|c|c|c|c|c|c|c|c|c|c|}
\hline \multirow[t]{2}{*}{ Observations } & \multicolumn{12}{|c|}{ Month } \\
\hline & 0 & $\mathbf{N}$ & D & $\mathbf{J}$ & $\mathbf{F}$ & $\mathbf{M}$ & $\mathbf{A}$ & $\mathbf{M}$ & $\mathbf{J}$ & $\mathbf{J}$ & $\mathbf{A}$ & $\mathbf{S}$ \\
\hline
\end{tabular}

1969/1970:

mean monthly

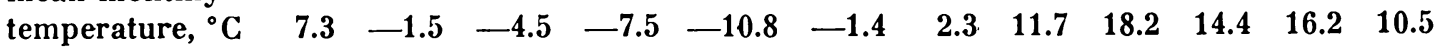

precipitation,

in $\mathrm{mm}$

$\begin{array}{llllllllllll}23 & 64 & 42 & 25 & 17 & 33 & 61 & 7 & 80 & 166 & 42 & 72\end{array}$

days with

snow cover

$\begin{array}{lllllll}- & 18 & 31 & 31 & 28 & 31 & 14\end{array}$

1970/1971:

mean monthly

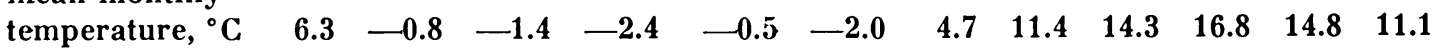

precipitation,

in $\mathrm{mm}$

days with

$\begin{array}{llllll}101 & 180 & 24 & 68 & 71 & 80\end{array}$

$\begin{array}{llllll}23 & 63 & 64 & 107 & 49 & 39\end{array}$

snow cover

$\begin{array}{llllll}3 & 24 & 13 & 13 & 24 & 31\end{array}$

$4--1-$

Housing. Most of the lambs were born in concrete pens with sawdust litter which was cleaned out daily. Few-day-old lambs were transferred to pens provided with wooden slatted floors.

Experimental animals. In these investigations ewes with twin lambs of the Dala breed were used. Some of the lambs on each pasture were treated against coccidiosis as a part of another experiment, but the animals used in this study were untreated.

In 1970 groups of six ewes and six lambs grazed on each 
of the two permanent and the two new pastures. In 197110 lambs grazed on the permanent pastures (eight on pasture No. 1 and two on pasture No. 2).

Grouping. In the spring the ewes were arranged in blocks according to their ages. The ewes were selected at random from each block to form each group on the different pastures. The lambs used for oocyst studies were selected at random in 1970, one from each twin pair being used while in 1971 they were selected entirely at random.

Anthelmintic treatment. All the sheep on one of the permanent pastures (No. 2) and one of the new pastures were treated fortnightly against nematodes with thiabendazole*. In 1970 half of the lambs on all pastures were treated against cestodes with niclosamid * .

Faecal examinations. Weekly faecal samples were taken from the rectum of each animal at the same time of day. Conical glass tubes were used for obtaining faecal samples from young lambs.

The oocysts were counted by a modified McMaster technique (Helle 1964, 1971a) and defined as oocysts per $\mathrm{g}$ of faeces (OPG). Eimeria intricata was not included in the total oocyst count. For obtaining sporulated oocysts, each faecal sample was suspended in $2.5 \%$ potassium dichromate solution and incubated for 4 days at $25^{\circ} \mathrm{C}$. The sediment from this suspension was washed with water, suspended in saturated salt solution, centrifuged for $3 \mathrm{~min}$. at 3000 r.p.m. and the oocysts collected from the surface of the solution. One hundred oocysts were differentiated using a high power objective $(X 400)$ according to the morphological characteristics of the species given by Christensen (1938), Levine (1961), Levine et al. (1962), Shah (1963), Pellèrdy (1965), Joyner et al. (1966) and Levine \& Ivens (1970).

The number of oocysts per $g$ of faeces for each Eimeria sp. was calculated from the total oocyst counts per $g$ on the bases of the percentage of the different species in each sample.

Statistical examinations. Comparisons between the different groups were carried out by using the Student's t-test as described by Helle $(1971 \mathrm{a}, \mathrm{b})$.

* Tiabendazolum (NFN, INN), Thibenzole $®$.

- Niclosamidum (NFN), Mansonil@. 


\section{RESULTS}

The total and differential oocyst counts for the lambs on the two permanent pastures were compared by the Student's t-test for each sampling day. It was found that there was no significant difference between the two groups from the beginning of the grazing period until 40 days later neither in 1970 nor in 1971 . Consequently, the data for the lambs on the permanent pastures within each year were pooled and compared with the pooled data for the lambs on the new pastures. No significant differences were observed between the lambs on the two new pastures during the grazing period in 1970. Negligible significant differences in the total and differential oocyst counts between the ewe groups were recorded. Consequently, the data of ewes on permanent pastures were pooled and the data of ewes on new pastures were treated in the same manner.

All the investigated ewes and lambs were found to harbour coccidial infections either permanently or intermittently during the grazing periods of 1970 and 1971 .

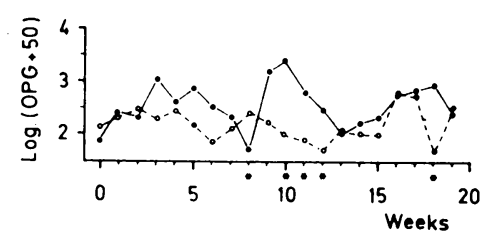

Figur e 1. Mean log. $(O P G+50)$ of all Eimeria spp. from pooled ewe groups on permanent (solid line) and new pasture (broken line) in 1970 .

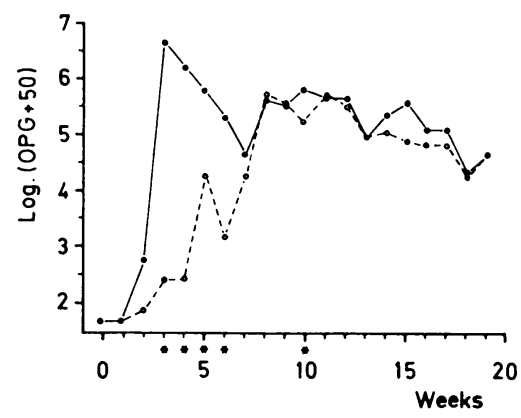

Figur e 2. Mean log. ( $O P G+50)$ of all Eimeria spp. from lambs on permanent (solid line) and new pastures (broken line) in 1970. Each asterisk below the abscissa shows that the difference of mean log $(O P G+50)$ between the groups was significant on that date at the $5 \%$ level, or higher degrees of significance. 

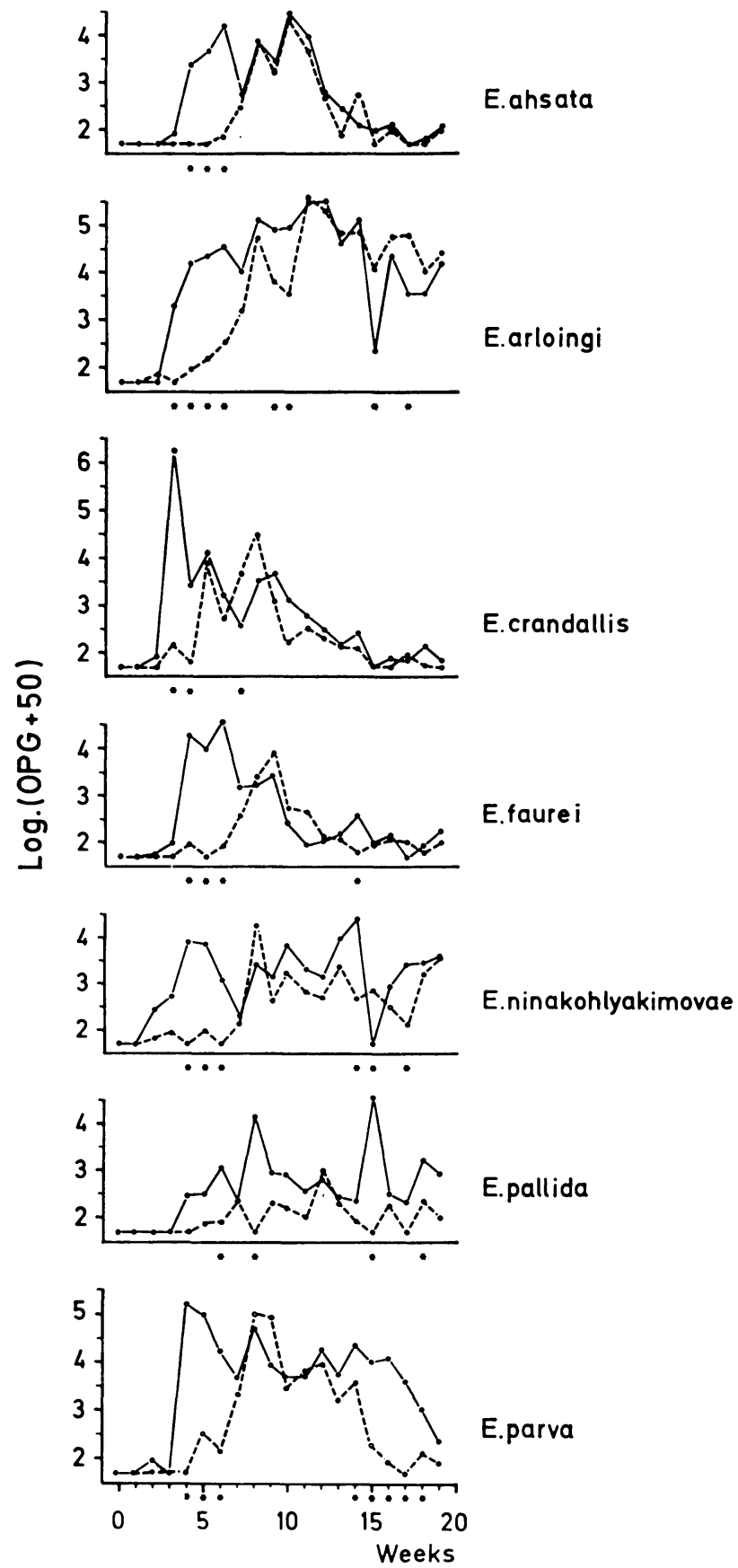

Figu r e 3. Mean log. $(O P G+50)$ of 7 Eimeria spp. from lambs on permanent (solid line) and new pastures (broken line) in 1970. (Asterisks and symbols as in Fig. 2). 
Fig. 1 shows the total number of oocysts in the faeces of the pooled ewe groups on permanent and new pastures in 1970.

Fig. 2 shows the total number of undifferentiated oocysts in the faeces of lambs on permanent and new pastures in 1970. Highly significant differences appeared 3 weeks after the beginning of the grazing period and continued during the following three sampling dates.

Fig. 3 shows the differential oocyst counts of the seven Eimeria spp. recorded from lambs on new and permanent pastures in 1970. The number of E. crandallis oocysts showed a steep rise 3 weeks after the beginning of the grazing period. These counts were significantly higher in lambs grazing on permanent pastures compared to these on new pastures. The numbers of E. arloingi oocysts in the two groups were also significantly different 3 weeks after the beginning of grazing with a more moderate increase in lambs on permanent pasture as compared to the increase for E. crandallis.

One week later, the differences in the number of oocysts between the two lamb groups were significant for E. ahsata, E. arloingi, E. crandallis, E. faurei, E. ninakohlyakimovae and E. parva, but not for E. pallida. For all species except E. crandallis and E. pallida the difference was significant during the following 2 weeks.

Fig. 4 shows the total number of undiffentiated oocysts in the faeces of lambs on permanent pasture in 1970 and 1971. As the sampling occurred on different dates during these years, no statistical comparisons were made, although the curves generally follow each other.

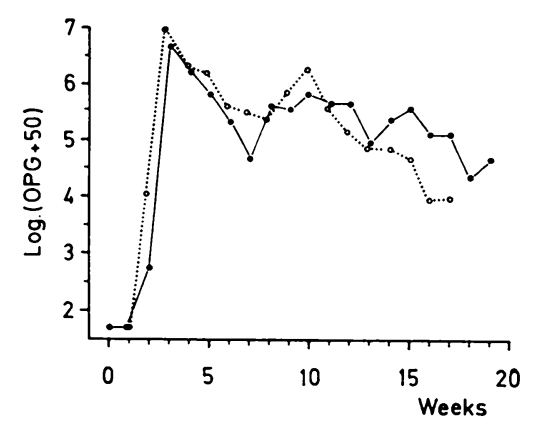

Figure 4. Mean log. $(\mathrm{OPG}+50)$ of all Eimeria species in lambs on permanent pasture in 1970 (solid line) and 1971 (dotted line). 


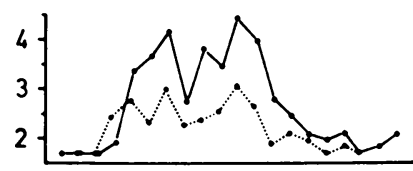

\section{E.ahsata}

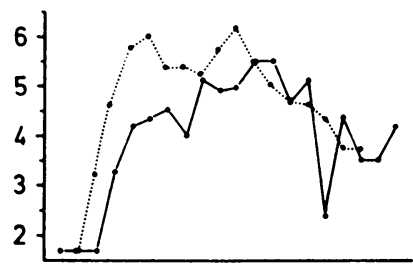

E.arloingi
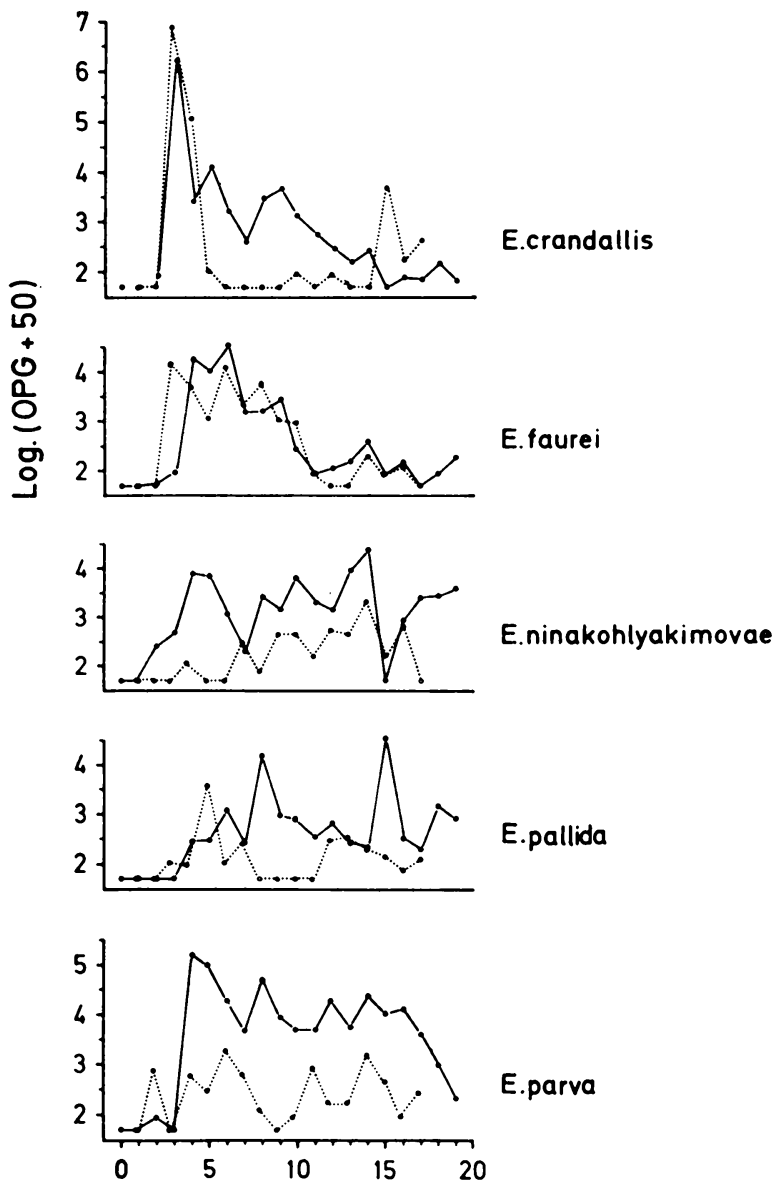

Weeks

F i g u r e 5. Mean log. of 7 Eimeria species from lambs on permanent pasture in 1970 (solid line) and 1971 (dotted line). 
Fig. 5 shows the differential oocyst counts for seven Eimeria species from lambs on permanent pasture in 1970 and 1971. The data for the 2 years have not been statistically compared for the reason mentioned above.

The total, as well as the differential numbers of oocysts in housed lambs did not deviate significantly from those of lambs on new pastures during the first 4 weeks after the beginning of the grazing period. No further investigations were carried out on the housed lambs.

\section{DISCUSSION}

The validity of using oocyst counis as a measure of the level of coccidial infection has been discussed previously by Helle (1970). The significant differences in the number of oocysts in the faeces of lambs on new and permanent pastures demonstrate that the oocyst counts can give general information about the level of infection in susceptible lambs. These findings are in agreement with the results of Helle (1970) but in contrast to those of Pout (1969).

In the present work, some problems were encountered during the differentiation of the Eimeria spp. infecting the sheep. The problems arose because of the fact that the morphological variations of the oocysts of the different Eimeria spp. are not well known. These difficulties will continue to exist until the life histories of the different Eimeria spp. can be studied after infection with only one species. The descriptions of the sporulated oocysts as given by Christensen (1938), Levine (1961), Levine et al. (1962), Shah (1963), Pellèrdy (1965), Joyner et al. (1966) and Levine \& Ivens (1970) also led to some difficulties in differentiating E. pallida from E. parva, E. parva from E. ninakohlyakimovae, E. ahsata from E. arloingi and E. arloingi from E. crandallis.

Although Levine \& Ivens consider E. ovina to be the correct name for $E$. arloingi in sheep, the latter name has been retained here for practical reasons.

The oocyst numbers were low for ewes on new as well as on permanent pastures. This confirms the previous results of Helle (1971 b) which indicate that the ewes are not a significant cause of the high oocyst counts for lambs grazing on permanent pastures.

The significant differences in the oocyst counts of E. ahsata, 
E. arloingi, E. crandallis, E. faurei, E. ninakohlyakimovae and E. parva in lambs grazing on permanent pasture compared to those on new pasture, show that all these species are able to survive the winter in the pasture under Norwegian climatic conditions. However, the number of oocysts in the faeces of lambs grazing on permanent pastures cannot be regarded as a sensitive criteria for a quantitative evaluation of the abilities of the different Eimeria spp. to survive the winter in the pasture. Eimeria crandallis showed the highest and earliest peak among the Eimeria spp. differentiated. This may be due to its shorter prepatent period (Pout 1965). The results would, however, indicate that this species should be considered as an important contributer to the clinical symptoms which are frequently observed in Norwegian lambs about $2-3$ weeks after the beginning of the grazing period (Helle 1970). It has been shown that Eimeria crandallis can induce marked clinical symptoms in sheep (Pout 1965).

Fig. 3 indicates that Eimeria pallida has difficulties in surviving the winter as significant differences between the lambs on permanent and new pastures occurred irregularly and later in the grazing period. Comparison of the results from the permanent pastures in 1970 and 1971 indicated some differences, especially for E. ninakohlyakimovae and E. parva, but also to some extent for E. ahsata and E. arloingi. The differences between the two latter species could be partially explained by the difficulties in differentiating the oocysts. E. crandallis gave similar results for both years.

As far as seasonal incidence is concerned, E. ahsata, E. arloingi, E. ninakohlyakimovae and E. parva developed a peak at approximately the same time whereas E.crandallis occurred earlier and E. pallida later in the grazing period. The fall in the number of oocysts is regarded as an expression of developing immunity. Duc to this fact valid informations about sheep infections with Eimeria spp. can only be obtained from the results during the period from 3-5 weeks after the beginning of the grazing period.

\section{REFERENCES}

Christensen, J. F.: Species differentiation in the coccidia from the domestic sheep. J. Parasit. 1938, 24, 453-467.

Helle, O.: Coccidiose hos sau. (Coccidiosis in sheep). Medlemsbl. norske Vet.-Foren. 1964, 16, 117-127. 
Helle, O.: Epidemiologien ved coccidiose hos sau i Norge. (The epidemiology of coccidiosis of sheep in Norway). Proc. X. Nord. Vet. Congr., Stockholm 1967, 929-934.

Helle, O.: Winter resistant oocysts in the pasture as a source of coccidial infection in lambs. Acta vet. scand. 1970, 11, 545-564.

Helle, $O .:$ The effect on sheep parasites of grazing in alternate years by sheep and cattle. A comparison with set-stocking, and the use of anthelmintics with these grazing managements. Acta vet. scand. 1971a, Suppl. 33, 59 pp.

Helle, O.: Gastrointestinal parasites in sheep on lowland pastures in eastern Norway. Acta vet. scand. 1971b, Suppl. 34, 118 pp.

Joyner, L. P., C. C. Norton, S. F. M. Davies \& C. V. Watkins: The species of coccidia occurring in cattle and sheep in the southwest of England. Parasitology 1966, 56, 531-541.

Levine, N. D.: Protozoan parasites of domestic animals and of man. Burgess Publ. Co., Minneapolis 1961, 412 pp.

Levine, N. D. \& V. Ivens: The coccidian parasites (Protozoa, Sporozoa) of ruminants. Univ. Illinois Press 1970, $278 \mathrm{pp}$.

Levine, N. D., V. Ivens, W. N. Smith \& L. R. Davis: A redescription of the oocysts of Eimeria ahsata Honess, 1942, from the domestic sheep. Proc. Helminth. Soc. Wash. 1962, 29, 87-90.

Lizcano Herrera, J. \& J. Romero Rodriguez: Epizootiologia de coccidiopatias de enteres veterinario en la provincia de Granada. (Epidemiology of coccidial disease of veterinary interest in Granada province, Spain). Rev. ibér. Parasit. 1969, 29, 143-190 and 427-432. (Ref. in Vet. Bull. (Weybridge) 1970, 40, 546).

Masi, R. \& C. B. Usher: (Coccidia in pig and sheep). Rev. Vet. milit. (B. Aires) 1970, 18, 102-103. (Ref. in Vet. Bull. (Weybridge) 1971, 41, 462).

Michael, E. \& A. J. Probert: The prevalence of coccidia in faecal samples from sheep in North Wales. Res. Vet. Sci. 1970, 11, $402-403$.

Pellèrdy, L. P.: Coccidia and coccidiosis. Adakemiai Kiado, Budapest 1965, $657 \mathrm{pp}$.

Pout, D. D.: Coccidiosis in lambs. Vet. Rec. 1965, 77, 887.

Pout, D. D.: Coccidiosis of sheep, a critical review of the disease. Vet. Bull. (Weybridge) 1969, 39, 609-618.

Pout, D. D., D. C. Ostler, L. P. Joyner \& C. C. Norton: The coccidial population in clinically normal sheep. Vet. Rec. 1966, 78, 455460.

Rohde, H. \& R. Jungmann: Untersuchungen zur Kokzidienfauna des Merinofleischschafes. (The coccidial fauna of Mutton Merino sheep). Mh. Vet.-Med. 1970, 25, 589-593.

Shah, H. L.: Coccidia (Protozoa: Eimeriidae) of domestic sheep in the United States, with descriptions of the sporulated oocysts of six species. J. Parasit. 1963, 49, 799-807. 
Soltys, A.: (The coccidia of sheep in Poland). Wiad. Parazyt. 1970, 16, 183-186. (Ref. in Vet. Bull. (Weybridge) 1970, 40, 700).

Tsaglis, A.: Ricerche svi coccidi della pecora e della capra in Grecia. (Research on coccidia of sheep and goats from Greece). Nuova Vet. 1970, 46, 117-129. (Ref. in Vet. Bull. (Weybridge) 1970, 40,770 ).

\section{SAMMENDRAG}

Differensiering av Eimeria-arter hos sau på permanente og nye beiter under norske forhold.

Det samlede antall oocyster og antallet av hver Eimeria-art $\mathrm{i}$ fæces hos sau ble unders $\varnothing \mathrm{kt}$ med en ukes intervaller hos dyr på permanente og nye beiter. Hos lam på permanent sauebeite var det totale antall oocyster signifikant høyere enn hos lam på nye beiter $3-6$ uker etter beiteperiodens begynnelse. Dette viser at oocyster kan overleve vinteren $\mathrm{i}$ beitet. Unders $\emptyset$ kelser av de enkelte artene viste at E. ahsata, E. arloingi, E. crandallis, E. ninakohlyakimovae, E. faurei og E. parva overlevet vinteren i beitet. E. crandallis opptrådte i størst mengde, og denne arten ansees for å være en vesentlig årsak til de kliniske symptomene på coccidiose som ofte sees hos lam $2-3$ uker etter utslipping. E. pallida hadde liten evne til a overleve vinteren $i$ beitet.

I to påfølgende år var det liten forskjell $\mathrm{i}$ opptreden av de fleste Eimeria-artene hos lam som gikk på de samme permanente beitene.

Lam som ble holdt inne 4 uker etter at de $\emptyset$ vrige lam var sluppet ut, viste ingen signifikante forskjeller i totalantall eller antall oocyster av de enkelte Eimeria-arter sammenliknet med lam på nye beiter.

Det totale antall og antall oocyster av de enkelte Eimeria-arter hos s $\varnothing$ yer var lavt gjennom hele beitesesongen. S $\phi$ yene ansees ikke for å være kilden til de høye oocystetall som finnes hos lam på permanente beiter.

(Received March 17, 1972).

Reprints may be requested from: Oddvar Helle, Parasitology Laboratory, Veterinary College of Norway, Postboks 8146, Oslo Dep., Oslo 1, Norway. 